City University of New York (CUNY) CUNY Academic Works

\title{
Violence, Mourning, Politics
}

Judith Butler

University of California - Berkeley

\section{How does access to this work benefit you? Let us know!}

More information about this work at: https://academicworks.cuny.edu/clags_pubs/54

Discover additional works at: https://academicworks.cuny.edu

This work is made publicly available by the City University of New York (CUNY).

Contact: AcademicWorks@cuny.edu 


\section{Violence, Mourning, Politics}

\author{
B Y J U D I T H B U T L E R
}

'd like to speak to you this evening on the matter of politics and, specifically, how the struggles of gender and sexual minorities might offer a perspective on current issues that are before us, questions of mourning and violence, which we have to deal with as part of an international community. I'd like to start, and to end, with the question of the human, of who counts as the human, and the related question of whose lives count as lives, and with a question that has preoccupied many of us for years: what makes for a grievable life. I believe that whatever our differences as a community, and there are many, we all have some notion of what it is to have lost somebody. And if we've lost, then it seems to follow that we have had, that we have desired and loved, and struggled to find the conditions for our desire. We have all lost in recent decades from AIDS, but there are other losses that inflict us, other diseases, and there is the fact as well that we are, as a community, subjected to violence, even if some of us have not been. And this means that we are constituted politically in part by virtue of the social vulnerability of our bodies, as a field of desire and physical vulnerability, of a publicity at once assertive and targeted.

I am not sure I know when mourning is successful, or when one has fully mourned another human being. I'm certain, though, that it does not mean that you have forgotten them, or that something else comes along to take their place. I don't think it works that way. I think instead that one mourns when one accepts the fact that the loss one undergoes will be one which changes you, changes you possibly forever, and that mourning has to do with agreeing to undergo a transformation the full result of which you cannot know in advance. So there is losing, and there is the transformative effect of loss, and this latter cannot be charted or planned. I don't think, for instance, you can invoke a protestant ethic when it comes to loss. You can't say, oh, I'll go through loss this way, and that will be the result, and I'Il apply myself to the task, and I'II endeavor to achieve the resolution of grief that is before me. I think you get hit by waves, and that you start out the day, with an aim, a project, a plan, and you find yourself foiled. You find yourself fallen. You're exhausted, and you don't know why. Something is larger than your own deliberate plan, your own project, your own knowing. Something takes hold of you, and what sense does this make? What is it that claims us at such moments, such that we are not the masters of ourselves? To what are we tied? And by what are we seized?

Is it simply the case that we are undergoing something temporary, or is it rather that, in undergoing what we do, something about who we are is revealed, something which delineates the ties we have to others, that shows us that the ties are what we are, what we are composed of, and that when we lose them, especially some of them, we do not know who we are, or what to do. Many people think that grief is privatizing, that it returns us to a solitary situation, but I think it has and can furnish a sense of political community of a complex order.

And it is not just that I might be said to "have" these relations, and sit back and enumerate them to you, explaining what this friendship means, what that lover meant or means to me. On the contrary, it seems that what grief displays is the way in which we are in the thrall of our relations with others in ways that we cannot always recount or explain, in ways that often interrupt the self-conscious account of ourselves we might try to provide, in ways that challenge the very notion of ourselves as autonomous and in control. I might try to tell a story here, about what I am feeling, but it would have to be a story in
CELEBRAIING A

\section{DECADE OF LGTBO SCHOLARSHP}

A standing-room-only crowd helped celebrate CLAGS's 10th birthday at the 10th Annual David R. Kessler Lecture on December 7, which featured Judith Butler, introduced by warm testimonials by David Eng and Biddy Martin. After the lecture, CLAGS supporters danced, dined, shmoozed, and, of course, debated the fine points of Butler's talk, at a benefit bash in the Graduate Center's skylight room. We are pleased to offer an excerpt from Butler's lecture here along with some photos of the festivities.

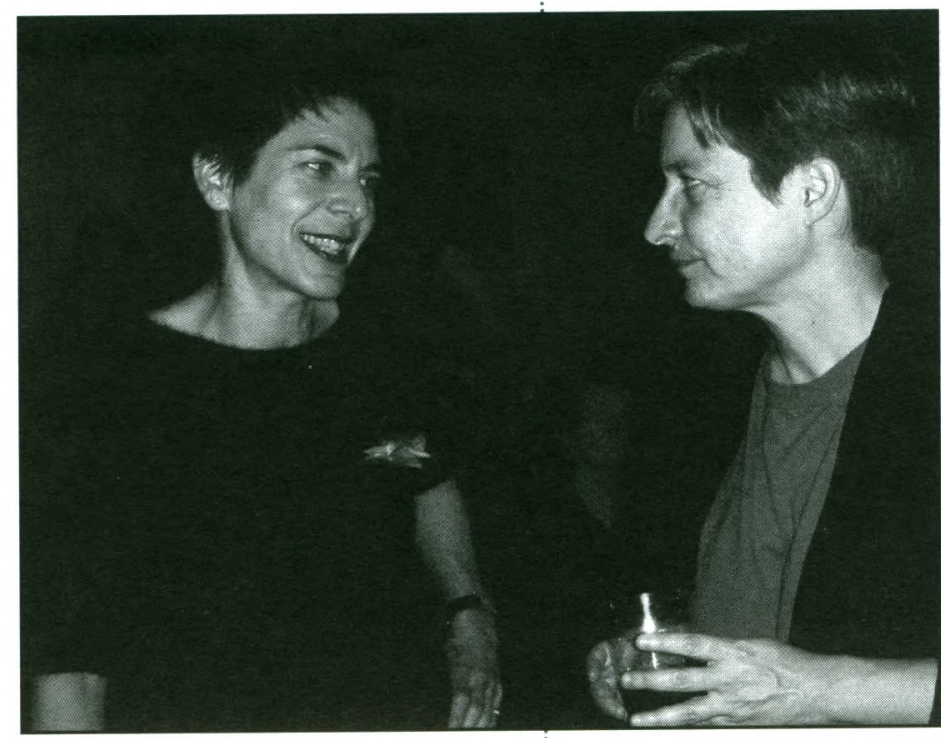

Board member Carolyn Dinshaw talks to Judith Butler, CLAGS's 10th Kessler honoree. 


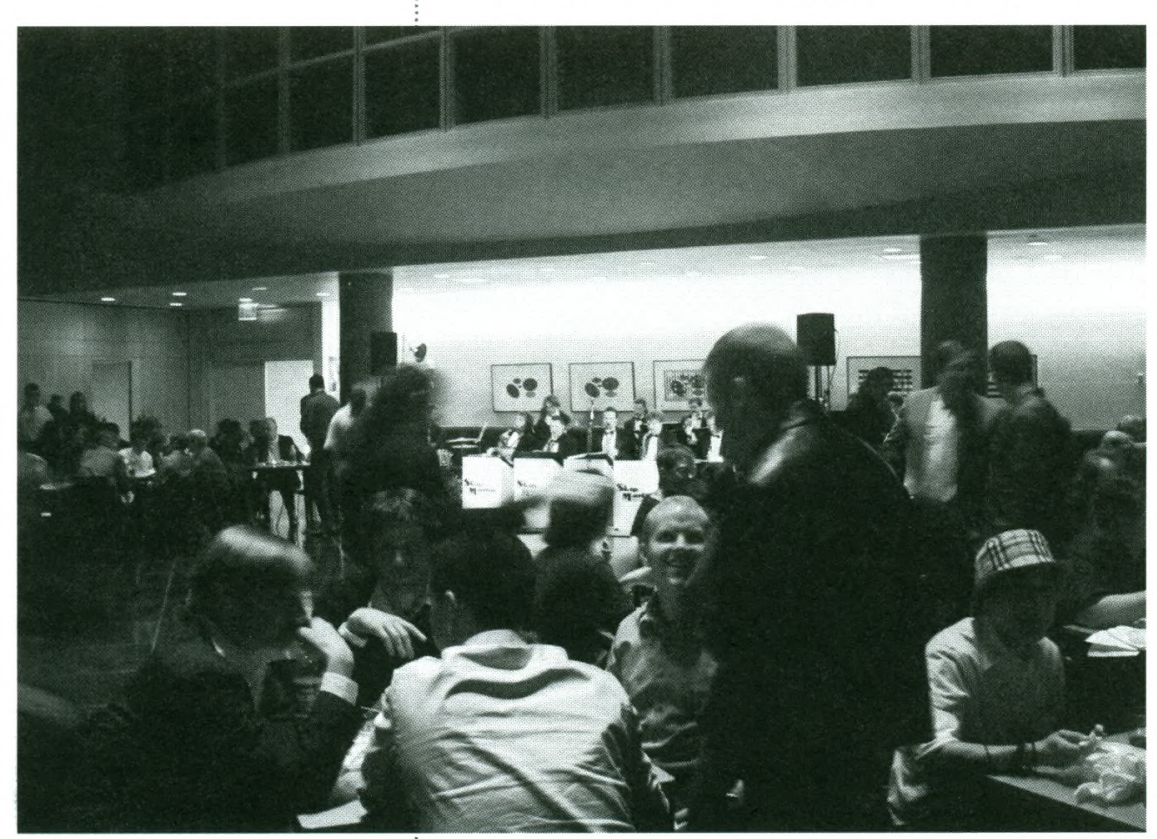

CLAGS members celebrate a decade of LGTBQ work with dancing and dining at the Graduate Center. which the very " $\mid$ " who seeks to tell the story is stopped in the midst of the telling, the very " $\mid$ " is called into question by its relation to the Other, a relation that does not precisely reduce me to speechlessness, but does nevertheless clutter my speech with signs of its undoing.

Let's face it. We're undone by each other. And if we're not, we're missing something.

This seems so clearly the case with grief, but this can be so only because it was already the case with desire. One does not always stay intact. It may be that one wants to, or does, but it may also be that despite one's best efforts, one is undone, in the face of the other, by the touch, by the scent, by the feel, by the prospect of the touch, by the memory of the feel. And so when we speak about my

sexuality or my gender, as we do, and as we must, we mean something complicated by it. Since it is not precisely a possession, but, rather, a mode of being dispossessed, a way of being for another, or by virtue of another. It won't even do to say that I am promoting a relational view of the self over an autonomous one, or trying to redescribe autonomy in terms of relationality. We tend to narrate the history of the movement in such a way that ecstasy figures in the '60s and '70s, and mid-way through the '80s. But maybe ecstasy is more persistent than that, maybe it is with us all along. To be ec-static means, literally, to be outside oneself, and this can have several meanings: to be transported beyond oneself by a passion, but also to be beside oneself with rage or grief. I think that if I can still speak to a "we", or include myself within its terms, I am speaking to those of us who are living in certain ways beside ourselves, whether it is in sexual passion, or emotional grief, or political rage.

I'm arguing, if I am "arguing" at all, that we have an interesting political predicament, since most of the time when we hear about "rights," we understand them as pertaining to individuals, or when we argue for protection against discrimination, we argue as a group or a class. And in that language and in that context, we have to present ourselves as bounded beings, distinct, recognizable, delineated, a subject before the law, a community defined by sameness. Indeed, we had better be able to use that language to secure legal protections and entitlements. But perhaps we make a mistake if we take the definitions of who we are, legally, to be adequate descriptions of what we are about. And though this language might well establish our legitimacy within a legal framework ensconced in liberal versions of human ontology, it doesn't do justice to passion and grief and rage, all of which tear us from ourselves, bind us to others, transport us, undo us, implicate us in lives that are not are own, fatally, irreversibly.

It is not easy to understand how a political community is wrought from such ties. One speaks, and one speaks for another, to another, and yet there is no way to collapse the distinction between the other and myself. When we say "we" we do nothing more than designate this very problematic. We do not solve it. And perhaps it is, and ought to be, insoluble. I don't want to forget that there are bodies here, and that bodies are in a certain sense our own, that over which we must claim rights of autonomy: this is as true for lesbian and gays rights claims in favor of sexual freedom as it is for transsexual and transgender claims to self-determination, as it is to intersex claims to be free of coerced medical and psychiatric interventions, as it is for all claims to be free from racist attacks, physical and verbal, as it is for feminism's claim to reproductive freedom. It is difficult, if not impossible, to make these claims without recourse to autonomy. And I am not suggesting that we cease to make these claims. We have to, we must. And I'm not saying that we have to make these claims reluctantly or strategically. They are part of any normative aspiration of a movement that seeks to maximize the protection and the freedoms of sexual and gender minorities, of women, defined with the broadest possible compass, of racial and ethnic minorities, especially as they cut across all the other categories. But is there another normative aspiration that we must also seek to articulate and to defend? Is there a way in which the place of the body in all of these struggles opens up a different conception of politics?

The body implies mortality, vulnerability, agency: the skin and the flesh expose us to the gaze of others, but also to touch, and to violence, and it can be the agency and instrument of all these as well. 
Although we struggle for rights over our own bodies, the very bodies for which we struggle are not quite ever only our own. The body has its invariably public dimension: and it is constituted as a social phenomenon in the public sphere, so that my body is and is not mine. If it is given over from the start to the world of others, bearing their imprint, formed within the crucible of social life, it is only later, and with some uncertainty, that I lay claim to my body as my own. Indeed, if I seek to deny the fact that my body relates me, and against my will, and from the start, to others I do not choose to have in proximity to myself, if I build a notion of "autonomy" on the basis of the denial of this sphere or a primary and unwilled physical proximity with others, then do I precisely deny the social and political conditions of my embodiment in the name of autonomy? If I am struggling for autonomy, do I not need to be struggling for something else as well, a conception of myself as invariably in community, impressed upon by others, impressing them as well, and in ways that are not fully predictable?

Is there a way that we might struggle for autonomy in many spheres, but also consider the demands that are imposed upon us by living in a world of beings who are, by definition, physically dependent on one another, physically vulnerable to one another. Is this not another way of imagining community, and imagining it in such a way that it becomes incumbent upon us to consider very carefully when and where we use violence, for violence is, always, an exploitation of that primary tie, that primary way in which we are, as bodies, outside ourselves, for one another.

If I might then return to the problem of grief, to the moments in which one undergoes something which is outside of one's control, finds that one is beside oneself, not at one with oneself, perhaps we can say grief contains within it the possibility of apprehending the fundamental sociality of embodied life, the ways in which we are, from the start, and by virtue of being a bodily being, already given over, beyond ourselves, implicated in lives that are not our own. Can this situation, one which is so dramatic for us, one which establishes a very specific political perspective for anyone who works in the field of sexual and gender politics, supply a perspective by which to begin to apprehend the contemporary global situation?

Mourning, fear, anxiety, rage. And in the US, we are everywhere now surrounded with violence, of having perpetrated it, having suffered it, living in fear of it, planning more of it. Violence is surely a touch of the worst order, a way in which the human vulnerability to other humans is exposed in its most terrifying way, a way in which we are given over, without control, to the will of another, the way in which life itself can be expunged by the willful action of another. To the extent that we commit violence, we are acting upon another, to put the other at risk, cause the other damage, to expunge the other. In a way, we all live with this particular vulnerability, a vulnerability to the other which is part of bodily life, but this vulnerability becomes highly exacerbated under certain social and political conditions, a vulnerability which becomes the basis of claims for non-militaristic political solutions, one which we cannot will away, one which we must attend to, even abide by, as we begin to think about what politics might be implied by staying with the thought of corporeal vulnerability itself.

I think, for instance, that we have seen, are seeing, various ways of dealing with grief, so that, for instance, William Safire,

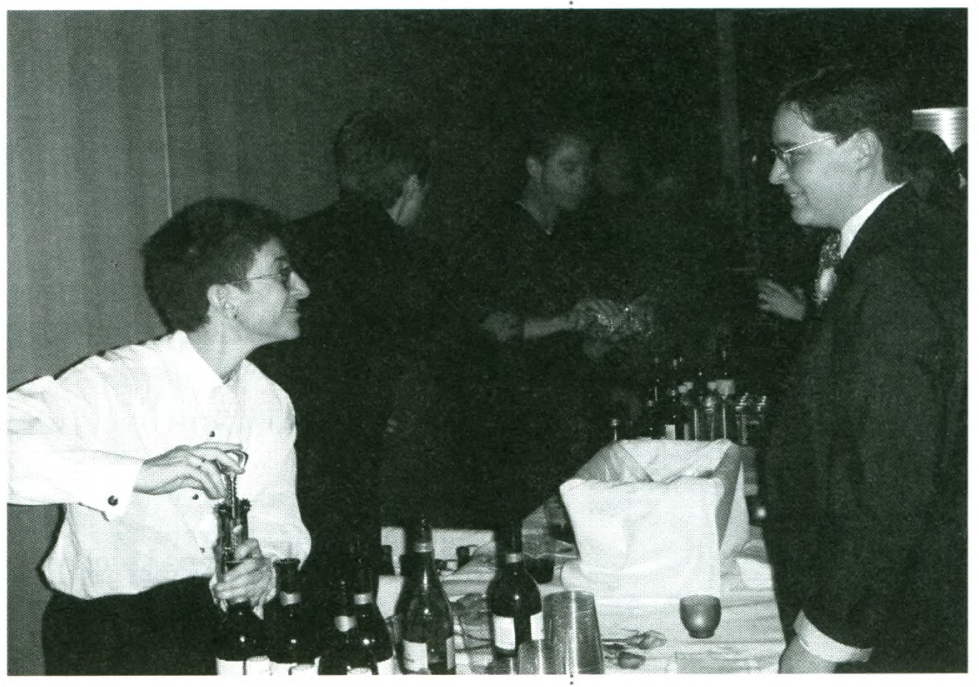
citing Milton, writes in the New York Times that we must banish melancholy, so that President Bush announces on September 21 st that we have finished grieving and that NOW it is time for resolute action to take the place of grief. When grieving is feared, it seeks to resolve itself quickly, to banish itself in the name of an action that is invested with the power to restore the loss or rectify the world. Is there something to be gained from grieving, from tarrying with grief, remaining exposed to its unbearability and not endeavoring to seek a resolution for grief through violence? Is there something to be gained in the political domain by maintaining grief as part of the framework by which we think our international ties? If we stay with the sense of loss, are we left feeling only passive and powerless, as some fear? Or are we, rather, returned to a sense of human vulnerability, to our collective responsibility for the physical lives of one another. The attempt to foreclose that vulnerability, to banish it, to make ourselves secure at the expense of every other human consideration, is surely also to eradicate one of the most important resources from which we must take our bearings, and find our way.

To grieve, and to make grief itself into a resource for politics, is not to be resigned to a simple passivity or powerlessness. It is, rather, to allow oneself to extrapolate from this experience of vulnerability

Alisa Solomon pours a drink for CLAGS Board member Deb Amory. 
to those of others, others whom we may well be able to protect from violence itself.

There is a more general conception of the human with which I am trying to work here, one in which we are, from the start, given over to the other, one in which we are, from the start, even prior to individuation itself, and by virtue of our embodiment, given over to an other: this makes us vulnerable to violence, but also to another range of touch, a range which includes the eradication of our being at the one end, and the physical support for our lives, on the other.

And there is a further point, which I hope will become clear in my comments to you today. And that is that we cannot recover the source of this vulnerability, for it precedes the formation of "l" and that this is a condition, a condition of being laid bare from the start, with which we cannot argue. I mean, we can argue with it, but we are perhaps foolish, if not dangerous, when we do. And of course, we can say that for some this primary scene is a scene of abandonment or violence or starvation, that these are bodies given over to nothing, or to brutality, or to no sustenance, but they still must be apprehended as given over, and part of understanding the oppression of lives is precisely to understand that there is no way to argue away this condition of a primary vulnerability, of being given over to the touch of the other, even if, or precisely when, there is no other there, and no support for our lives. And another part countering oppression involves understanding that lives are supported and maintained differentially, that there are radically different ways in which human physical vulnerability is distributed across the globe. Certain lives will be highly protected, and the abrogation of their claims to sanctity will be sufficient to mobilize the forces of war. And other lives will not find such fast and furious support and will not even qualify as "grievable."

A hierarchy of grief could no doubt be enumerated, and we've seen it already, in the genre of the obituary, where lives are so quickly tidied up and summarized, humanized, usually married, or on the way to be, heterosexual, happy, monogamous. But this is just a sign of another differential relation to life, since we rarely, if ever, hear the names of the thousands of Palestinians who have died by Israeli military with US support, of any number of Afghani people, children and adults. What defense against the apprehension of loss is at work in the blithe way in which we accept deaths caused by military means with a shrug or with self-righteousness or with clear vindictiveness? Do those who support the war consider these as lives at all? Do they conform to the notion of the human? And if not, what are the cultural contours of the notion of the human at work here? And how do the contours that we accept as

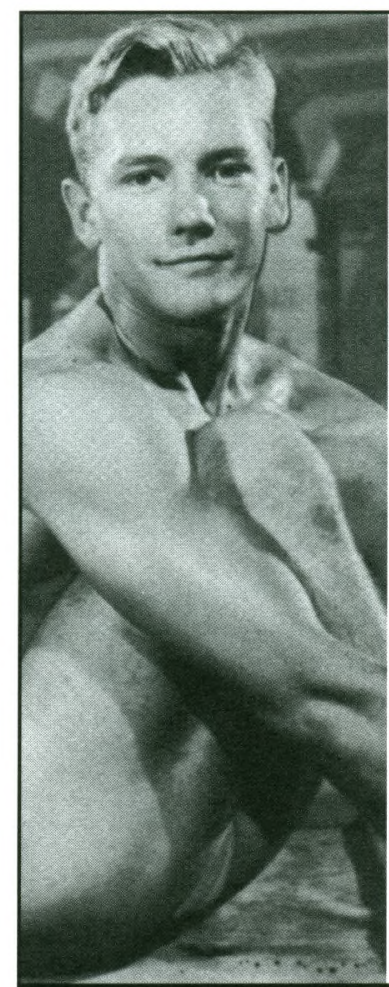

\section{Foundlings}

Lesbian and Gay Historical

Emotion before Stonewall

\section{CHRISTOPHER NEALON}

"Foundlings provides a new paradigm for thinking historically and theoretically about the longing for history within gay and lesbian texts."-Bill Brown, author of The Material Unconscious: American Amusement, Stephen Crane, and the Economies of Play

"A first-rate, innovative, and unprecedented work that will take the literary world by storm. Christopher Nealon proves himself here to be the very best of a new generation of queer theorists."-Judith Butler

224 pages, 2 photos, paper $\$ 18.95$ Series $Q$

\section{Duke University Press}

the cultural frame for the human limit the extent to which we can avow loss as loss? This is surely a question that lesbian, gay and bi-studies has asked, in relation to violence against sexual minorities, that transgendered people have asked as they have been singled out for harassment and sometimes murder, that intersexed people have asked, whose formative years have so often been marked by an unwanted violence against their bodies in the name of a normative notion of the human, a normative notion of what the body of the human must be. This is no doubt as well the basis of a profound affinity between movements revolving around gender and sexuality with efforts to counter the normative human morphologies and capacities that condemn or efface those who are physically challenged. And it must also be part of the affinity with anti-racist struggles, given the racial differential that undergirds the culturally viable notions of the human, ones that we see acted out in dramatic and terrifying ways in the global arena at the present time.

Judith Butler is Maxine Elliiot Professor in the Departments of Rhetoric and Comparative Literature at the University of California, Berkeley. She is the author of Subjects of Desire: Hegelian Reflections in Twentieth-Century France; Gender Trouble: Feminism and the Subversion of Identity; Bodies That Matter: On the Discursive Limits of "Sex"; The Pyschic Life of Power: Theories of Subjection; Excitable Speech; and Antigone's Claim: Kinship Between Life and Death. 